\title{
OBRACHUNKI WEBEROWSKIE. PARE UWAG O OBECNOŚCI MYŚLI MAXA WEBERA W FORMULE WSPÓŁCZESNEGO KAPITALIZMU
}

\begin{abstract}
Max Weber (1864-1920) to jeden z „ojców założycieli” współczesnej socjologii. Jego socjologia, podporządkowana zasadom racjonalności i obiektywizmu - Weber nazywał ją „socjologią rozumiejącą" - wpisuje się w orientację humanistyczną, której rdzeniem jest teza o zasadniczej odmienności świata przyrody od świata kultury. W klasycznej już dziś pracy Etyka protestancka i duch kapitalizmu (1905), Weber próbuje udowodnić, że genezę i byt kapitalizmu można pojąć jedynie przy uwzględnieniu wpływu etyki protestantyzmu na kształtowanie się zachowań przedsiębiorczych w społeczeństwach Zachodu. W pozytywnej na ogół recepcji teorii Webera pojawiają się też tony krytyczne. Krytyka dotyczy głównie teorii biurokracji, która nie znajduje już uznania i została zastąpiona koncepcjami w większym stopniu uwzględniającymi rolę kapitału ludzkiego. Biurokrację wskazuje się jako system anachroniczny. Pojawiają się też zastrzeżenia do tego, że Weber niedokładnie przedstawił dialektykę rozwoju kapitalizmu, gdyż po traktował purytanizm jako siłę mającą ten sam potencjał na każdym etapie tego procesu. Obecność Webera we współczesnej myśli społecznej przejawia się w szczególności w częstym odwoływaniu się do jego tez przez cytowanie i komentowanie $\mathrm{z}$ różnych perspektyw badawczych. W formule współczesnego kapitalizmu, ekspansywnego i realizowanego w różnych ujęciach modelowych, z których każde zakłada prymat zysku, znaleźć można odniesienia do tezy Webera o rachunku korzyści jako głównej siły napędzającej ludzką przedsiębiorczość i poszukującej legitymizacji

w etyce.

Słowa kluczowe: Max Weber, etyka protestancka, duch kapitalizmu, biurokracja, zarządzanie, legitymizacja, formuła współczesnego kapitalizmu.
\end{abstract}

Max Weber (1864-1920) to uczony dużej miary, jego wpływ na nie tylko na socjologię, ale i na myśl społeczną sensu largo w wielu jej nurtach, zasługuje na miano znaczącego $^{2}$. Należy podkreślić, że socjologia Webera, ufundowana na zasadach racjonalności i obiektywizmu, wykraczała poza konteksty wyznaczane przez socjologów jego epoki. Max Weber nie zbudował wprawdzie syntezy myśli socjologicznej, jednakże

${ }^{1}$ Mgr Wiesław Setlak, Wydział Filologiczny, Uniwersytet Rzeszowski, al. mjr. W. Kopisto 2 B, 35315 Rzeszów, tel. +48 178721204 e-mail: emily0383@gmail.com

${ }^{2}$ Fakt ten należy łączyć (w dużym stopniu) z fenomenalną erudycją i skalą zainteresowań Webera, który „uprawiał” nie tylko socjologię, ale też zajmował się prawem (wykładał prawo w Berlinie), historią gospodarczą i ekonomią polityczną, którą wykładał na Uniwersytetach we Fryburgu i Heidelbergu, komparatystycznymi badaniami dziejów religii, metodologią nauk społecznych, teorią polityki. Por. J. Szacki, Historia myśli socjologicznej. Część druga. wyd. 2, Warszawa 1983, s. 516. Z kolei Reinhard Bendix pisze wprost: „Max Weber to magiczne nazwisko współczesnej myśli społecznej [...] i nawet surowi krytycy nie zaprzeczają wartości jego wkładu do nauki”. R. Bendix, Max Weber. Portret uczonego, wyd. 1 thum. S. Kowalski, Warszawa 1975, s. 1. 
otworzył przestrzeń dla wielu koncepcji i teorii, a jego imponująca komparatystyka inspirowała całe pokolenia późniejszych badaczy świata społecznego. Można więc powiedzieć, że skala recepcji myśli Webera potwierdza czy - jeśli użyć bliskiego mu określenia - „legitymizuje” pogląd o wyjątkowości niemieckiego uczonego.

Niniejszy artykuł jest próbą uchwycenia kilku oznak obecności myśli Maxa Webera w dzisiejszym pojmowaniu kapitalizmu poprzez skonfrontowanie jego ustaleń z tym, co można określać jako „formułę współczesnego kapitalizmu”. Ta formuła to splot postulatów oraz interpretacji o charakterze ekonomicznym i filozoficznym. Autor poddaje je swoistej „cenzurze” z punktu widzenia aksjologii chrześcijańskiej, bliższej jednak katolicyzmowi niż protestantyzmowi. Jego wypowiedź dystansuje się od definitywnych rozstrzygnięć, próbuje jedynie zwrócić uwagę na rolę czasu i ewolucji w odbiorze socjologii Webera refleksją nad jej ,zderzeniem” z humanizmem chrześcijańskim i niektórymi tego stanu rzeczy skutkami. Celem wypowiedzi jest oznaczenie ogólnych konturów wskazanego zjawiska na szerszym tle ekonomicznym.

Max Weber tworząc model socjologii dystansującej się od wartościowania, zareagował na określoną sytuację. Otóż nauka w epoce nowożytnej podejmowała nieustanne próby koegzystowania z religią, czego skutkiem były swoiste separatyzmy. Sprowadzały się one do przypisywania odrębnych funkcji nauce i religii oraz wzajemnego poszanowania wyznaczonych tym formacjom terytoriów. W Weberowskiej doktrynie socjologii nieoceniającej, której istotą jest „przepaść pomiędzy nauką a wartościami”3, znaleźć można tropy prowadzące w stronę ,tej właśnie tradycji; uznać ją można za protestancką wersję tomistycznej próby zharmonizowania ich wzajemnych relacji"4. Próbę taką podejmuje Weber w napisanej w roku 1904, wydanej zaś w następnym roku pracy Etyka protestancka a duch kapitalizmu. W tym dziele stara się objaśnić na przykładzie dyfuzji kultury ekonomicznej i kultury religijnej zależność pomiędzy religią a zmianą społeczną.

Jest to przykład ,intencji” integracjonalistycznej, zatem z natury rzeczy opozycyjnej wobec wspomnianych wcześniej inklinacji separatystycznych, sytuującej religię na pozycji czynnika zmiany społecznej. Weberowski „duch kapitalizmu” można rozumieć jako zespół zachowań, postaw, preferencji składających się na portret homo oeconomicus $^{5}$. Daleki jest jednak od klasycznego wzorca, albowiem ma on swoje źródła w protestanckiej (dokładniej - w purytańskiej) etyce.

Max Weber zauważa także, ,że protestanci (a zwłaszcza pewne ich odłamy [...], zarówno jako warstwa panująca, jak i podległa, jako większość lub jako mniejszość, wykazywali specyficzną skłonność do racjonalizmu, której nie spotykało się i nie spotyka ani w jednej, ani w drugiej sytuacji u katolików. Przyczyny różnego zachowania trzeba szukać w trwałej wewnętrznej specyfice, a nie w zmiennej, zewnętrznej, historyczno - politycznej sytuacji tych wyznań."6 Niemiecki socjolog wyraźnie wskazuje na istotne

\footnotetext{
${ }^{3}$ A.-W. Gouldner, Anty-Minotaur, czyli mit socjologii wolnej od wartości, tłum. E. Morawska, [w:] Kryzys i Schizma. Antyscjentystyczne tendencje w socjologii wspótczesnej, red. E. Mokrzycki, t. 2, wyd. 1, Warszawa 1984, s. 37.

4 Ibidem. Weber przeciwstawia rozum (racjonalność) znajdujący spełnienie głównie w nauce i biurokracji, atawistycznej energii emocjonalnej, które to moce uważa za nieprzyjazne sobie. Jednakże są one jednakowo niebezpieczne, jak i konieczne. Por. ibidem, s. 37.

${ }^{5}$ G. Kehrer, Wprowadzenie do socjologii religii, tłum. J. Piegza, Kraków 1996, s. 48.

${ }^{6}$ M. Weber, Etyka protestancka a duch kapitalizmu, tłum. J. Miziński, Lublin 1994, s. 23-24.
} 
różnice w dwóch równolegle rozwijających się etosach inspirowanych wspólną chrześcijańską aksjologią. Skąd więc późniejsze antagonizmy? Tego już Max Weber nie wyjaśnia, zakładając niejako a priori immanentny charakter procesu formowania się etyki protestanckiej i katolickiej, przy czym w protestantyzmie dominantą jest etos „gospodarza” (homo oeconomicus), zaś w katolicyzmie - ethos „rycerza” czy etos pielgrzyma (homo viator).

Po rozważeniu tych wniosków można przyjąć, że rozumienie etyki protestanckiej przez Webera ma charakter kulturalistyczny. Jest to uzasadnione, albowiem kulturalizm dotyczy nie tylko nauk czy sztuk, ale też religii i gospodarki ${ }^{7}$. Z tego też względu myśl niemieckiego uczonego doczekała się pewnej recepcji w antropologii kultury, antropologii społecznej, czyli ujmując rzecz szerzej - w kulturologii.

W naukach społecznych już od niemal stu lat toczy się debata, nierzadko przechodząca w dyskurs, nad wpływem przemyśleń Maxa Webera (nazwijmy je tezami) ${ }^{8}$ na interpretację kapitalizmu w aspekcie wpływu na jego formułę oraz zmiany w tej formule czynnika religijnego. Jeżeli autor niniejszego tekstu miałby zabrać głos w owej debacie, to proponowałby nazywanie tej odmiany weberyzmu w porównywalnej mierze „socjologią genetyczną nowożytnego kapitalizmu” co „fenomenologią kapitalizmu”. Zalecałby też przyjrzenie się problemowi przez pryzmat równolegle rozwijającej się myśli aksjologicznej ze wszelkimi tego rozwoju uwarunkowaniami. Należałoby uwzględnić nie tyle etykę protestancką, okrzepłą już w czasach reformacji i mało modyfikowalną, co przede wszystkim doktrynę społeczną Kościoła. Ta druga bowiem okazała się formą nader pojemną dla wielu idei czy postulatów neotomizmu, solidaryzmu, a także chrześcijańskiej antropologii wspomaganej przez „odrodzoną” metafizykę i personalistyczną koncepcję człowieka.

Zastanawiając się nad strategią analityczno-interpretacyjną optymalnie sprzyjającą ustaleniu - przynajmniej z ograniczoną dokładnością - obecności i miejsca tez Maxa Webera we współczesnej formule kapitalizmu, można przyjąć (za Alvinem W. Gouldnerem), że „będzie to opowieść o micie stworzonym przez wspaniałego Minotaura imieniem Max. [...] Mit ten głosi, że socjologia może i powinna być wolna od wartości. Leże tego Minotaura, choć dotrzeć do niego można jedynie z pomocą logiki labiryntowej i choć dociera tam bardzo niewielu, a ci nigdy nie powracają, przez wielu socjologów nadal uważane jest za miejsce święte. Im starsi, socjologowie zdają się odczuwać rosnący przymus odbycia pielgrzymki do tego miejsca, by złożyć hołd problemowi zależności miedzy wartością a nauką społeczną"". Należy dodać, że takowy przymus jest właściwy nie tylko zawodowym socjologom, ale również humanistom,

${ }^{7}$ A. Mencwel, Wyobraźnia antropologiczna. Próby i studia, Warszawa 2006, s. 47.

${ }^{8}$ Ujęcie Webera uznawane jest za najbardziej wszechstronny i bogaty w koncepty obraz struktury społecznej. Istotne jest to, że tezy Webera zepchnęły w niepamięć powszechniki charakterystyczne dla mocno już anachronicznej kategorii homo oeconomicus, a także umożliwiły rozbrat ze zbyt wulgarnymi (bo mocno zawężonymi) koncepcjami Karola Marksa i epigonów. W rezultacie, na co zwraca uwagę Geoffrey Ingham, „Weberowi udało się wyróżnić swoiste historyczne elementy składowe owego osobliwego i niepowtarzalnego systemu gospodarczego, opierającego się na nieustannym obrachowywaniu szans na zysk, który narodził się i rozwinął w Europie Zachodniej u progu epoki nowożytnej”. Zob. G. Ingham, Kapitalizm, tłum. S. Królak, K. Sosnowska, Warszawa 2011, s. 47. Por. R. Collins, Weberian Sociological Theory, Cambridge MA, 1986.

${ }^{9}$ A.W. Gouldner, op. cit., s. 35. 
zwłaszcza tym, dla których odwieczny podział nauk na przyrodnicze, społeczne i humanistyczne nie jest przekonujący. Wyrazem tego przeświadczenia będzie niniejsza wypowiedź ${ }^{10}$.

A ma to być „opowieść” o tym, czy „myślenie wartościami”, które nazwać można też bardziej uczenie - myśleniem aksjologicznym, ma wpływ na oceny współczesnego kapitalizmu przez badaczy $\mathrm{z}$ różnych domen nauki i czy można jeszcze mówić o aktualności Webera. Jeśli tak, to czym i w jakim stopniu wyraża się jego wpływ na postrzeganie i weryfikowanie (czy też falsyfikowanie) doktryny kapitalizmu?

Węgierska filozof Ágnes Heller, uczennica jednego z najbardziej wpływowych marksistów XX stulecia, György’a Lukácsa, w eseju Marx and Modernity z roku 1983 analizuje myśl wielkich w jej przekonaniu „odkrywców” nowoczesności. Jednym z nich, obok Georga Friedricha Wilhelma Hegla i Karola Marksa, jest Max Weber ${ }^{11}$. Zdaniem autorki, Webera można uważać nie tylko za wczesnego przedstawiciela perspektywy ponowoczesnej, ale i - co jest porównywalnie zasadne - myśliciela reprezentującego dojrzały modernizm ${ }^{12}$.

Jako modernista Weber opowiada się za logiką technologii, z której to logiki ,wynika: 1) konkretny charakter umiejętności i profesji oraz 2) racjonalizacja instytucji, niezależnie od tego, czy mają cokolwiek (bezpośrednio) wspólnego z technologią, produkcją itd. Wzrastająca specjalizacja umiejętności potrzebnych do pracy w fabryce może pozytywnie wpłynąć na produkcję, ale to, że biurokracja nowoczesna - w wyniku rosnącej biurokracji - staje się bardziej efektywna, było złudzeniem Maxa Webera"13. Otóż stworzył on komentowany do dzisiaj model idealnej biurokracji, jeśli założyć, że biurokracja to pewien rodzaj porządku społecznego, czyli instytucji mającej formę biura. Ma ona działać bezosobowo i efektywnie, dawać pewność bezkolizyjnego funkcjonowania ${ }^{14}$. Biurokracja ma działać na zasadzie racjonalnej prawomocności warunkowanej przez porządek bezosobowy i formalną legalność. Warunki te mają zabezpieczać efektywność. Efektywność z kolei ma źródło w racjonalności, proceduralnej powtarzalności oraz dyscyplinie $^{15}$.

\footnotetext{
${ }^{10} \mathrm{~W}$ tym kontekście można się zastanawiać, czym jest socjologia we współczesnej wersji. Bada i opisuje świat coraz bardziej zawiłych relacji człowieka (centralnej kategorii tradycyjnej humanistyki) z drugim człowiekiem i grupami ludzi. Relacje te dotyczą różnych układów i systemów społecznych. Od pewnego czasu socjologia zdradza też skłonność do antyscjentyzmu.W tym kontekście nie jest w zasadzie błędem uważanie jej za naukę humanistyczną.

${ }_{11} \mathrm{~W}$. Bulita, W poszukiwaniu arché. Wprowadzenie do teorii nowoczesności Ágnes Heller, [w:] Á. Heller, Eseje o nowoczesności, tłum. J. P. Hudzik, W. Bulita, T. Markiewka, R. Kubicki, Toruń 2012, s. 11. Por. G. Lukács, Theory of the Novel, Cambridge MA, 1971. We wskazanej pracy węgierski filozof uzasadnia swój permanentny zwrot ku modernizmowi.

12 Á. Heller, Eseje..., op. cit., s. 99.

${ }^{13}$ Ibidem, s. 177.

${ }^{14}$ K. Czainska, Odkryć zarzadzanie. Wybrane koncepcje, Warszawa 2010, s. 38.

${ }^{15}$ Por. K. Szczerski, Porzadki biurokratyczne, Kraków 2004, s. 19-22. Warto podkreślić, że Max Weber swoje ,złudzenie" ufundował nie na czysto teoretycznych spekulacjach, lecz na analizie danych $\mathrm{z}$ empirycznych badań nad wydajnością pracy. Wykorzystał m.in. dane statystyczne odnoszące się do kwestii płac, rezultaty działania zegarów kontrolnych, krzywe wydajności pracy w poszczególnych godzinach, dniach, tygodniach, miesiącach etc. Por K. Jaremczuk, Koncepcje zarządzania wspótczesna organizacja, [w:] Zarządzanie w zarysie, red. K. Jaremczuk, Przemyśl -Rzeszów 2011, s. 35-36.
} 
Racjonalność, proceduralność, dyscyplina to wartości znajdujące uznanie w prakseologii. Jednakże we współczesnym zarządzaniu realizowanym zarówno w wymiarze kapitalizmu globalnego, jak i wymiarze partykularnym (organizacje mniejsze i niekoniecznie zinternacjonalizowane, które są zdolne sprostać wymogom gospodarki opartej na wiedzy, problem, o którym mowa, staje się bardziej złożony. Otóż w nowoczesnej gospodarce kapitalistycznej preferuje się innowacyjność, a w konsekwencji wzrasta znaczenie niekonwencjonalnych - przynajmniej w odniesieniu do modelu Webera - strategii i stylów zarządzania. Formuła zarządzania biurokratycznego sensu stricto nie trafiła może do lamusa historii, lecz jest ona poniekąd „piętnowana” przez rzeczników nowoczesnego zarządzania i wskazywana jako przykład nieefektywnego konserwatyzmu.

Współczesny kapitalizm charakteryzuje się zmianami instytucjonalnymi będącymi reakcjami na zwiększanie się ekonomicznej wartości jednostek ludzkich. Sytuacja ta wymaga tworzenia nowych modeli ekonomicznych. Noblista Theodore W. Schultz za najważniejsze spośród nich uważa:

„1) instytucjonalne reakcje na wzrost rynkowej ceny pracy;

2) instytucjonalne reakcje na wzrost stopy zwrotu z inwestycji w kapitał ludzki;

3 ) instytucjonalne reakcje na wzrost dochodu do dyspozycji konsumentów"16.

Wymienione modele ekonomiczne uwzględniają rzeczywistość ekonomiczno -społeczną, która dla współczesnych ekonomistów czy socjologów jest równie nieprzejrzysta i emergentna jak w charakterystyce Webera. Modelowanie działań zinstytucjonalizowanych w skali makroekonomicznej przekracza nieraz ramy pojedynczej narodowej gospodarki. Jest to następstwem globalizacyjnej integracji. Można je porównywać z próbami zaprowadzenia ładu gospodarczego wykorzystaniem systemu biurokracji według konceptu Maxa Webera. Rodzi to określone konsekwencje aksjologiczne, ponieważ większości spraw pojawiających się na styku jednostki z systemem zarządzania nie można ,załatwić” w formie prostego i korzystnego dla obu stron aktu decyzyjnego.

Jeżeli w zarządzaniu, którego przestrzenią jest szeroko rozumiane życie społeczne, dochodzi do dysfunkcji czy patologii, to ,praprzyczyny” takich zdarzeń szukać należy, jak się wydaje, w „błędzie antropologicznym”. Błąd ten polega na przyjęciu błędnej koncepcji człowieka. Można ją rozumieć jako „spłaszczenie” osoby (wbrew personalizmowi) do wymiaru jednostki (jak chce liberalizm). Można też mówić o fikcyjnym charakterze retoryki podmiotowości czy redukcji pierwiastka metafizycznego w naturze człowieka zubażającej uzasadnienie jego możliwości transgresyjnych.

W tym ostatnim rozumieniu znać wyraźne odcięcie się od tradycji metafizycznej, co jest niejako powieleniem błędu Maxa Webera, który próbował stworzyć zanadto autonomiczny system socjologii. Uwzględnił on pewne wątki filozofii historii Hegla i stworzył podstawy nowoczesnej socjologii religii. Są to jednak usiłowania niewystarczające, bo zawężone do analizy i interpretacji raczej behawioralnej, co wynika wprost z konsekwencji metodologicznej Webera. Niemiecki uczony zakładał bowiem racjonalność i obiektywizm. Przykładem może być jego charakterystyka podstawowych założeń ontycznych i teleologicznych kapitalistycznej gospodarki prywatnej. Otóż Weber podkreślał, ,że racjonalizuje ona działanie na bazie dokładnej rachunkowej konkluzji. Że

\footnotetext{
16 T.W. Schultz, Ekonomia kapitału ludzkiego, tłum. A. Kliber, P. Kliber, Warszawa 2014, s. 263.
} 
jest planowo i trzeźwo ukierunkowana na sukces gospodarczy, w przeciwieństwie do chłopskiego życia cechowego oraz «kapitalizmu awanturniczego», opartego na wykorzystywaniu szans politycznych i na racjonalnej spekulacji"17.

Wracając do głównego nurtu rozważań, warto zaznaczyć, że wszelkie teorie społeczne niedostatecznie umocowane w poznaniu filozoficznym ( $\mathrm{z}$ akcentem na metafizykę, transcendentalizm czy indeterminizm) nie mogą być długowieczne. Przeważnie - wcześniej czy później - okazują się „spolegliwe” wobec coraz bardziej spektakularnych zdobyczy empiryzmu i mało odporne na racjonalistyczne weto. Wydaje się, że stwierdzenie to można odnosić do postawy naukowej Webera. Zawierzył on zanadto idei oraz metodom racjonalnego i obiektywnego poznania naukowego.

Tak więc trzeba się zgodzić z Paweł Skrzydlewski uważa, że błędy antropologiczne, najrychlej pojawiają się w niefilozoficznych teoriach społecznych. Preferują one bardziej scjentystyczne $^{18}$ niż refleksyjne ujmowanie przedmiotów konceptualizacji (poznania i opisu). Muszą więc prowadzić do wyabstrahowania teorii ze świata idei. A to oznacza odwrót od tych wartości dostarczanych przez filozofię, głównie niematerialistyczną. W historii europejskiej kultury, zwłaszcza w dziejach polityki, wskazać można wiele przykładów na to, że ,błędne i fałszywe tezy filozoficzne u podstaw teorii prowadzą w końcu do sytuacji, gdy sama rzecz, w tym przypadku rzeczywistość społeczna, zostaje poddana błędnej interpretacji”"19.

Za przykład może tu posłużyć pogląd Maxa Webera na temat oczywistego w powszechnym mniemaniu związkowi parlamentyzacji i demokratyzacji. Zdaniem autora Wirtschaft Und Gessellschaft. Grundriss der verstehenden Soziologie ${ }^{20}$ „parlamentyzacja i demokratyzacja wcale niekoniecznie warunkują się wzajemnie, bo często pozostają w konflikcie. Ostatnio sądzi się nawet nierzadko, że w nieuchronnym konflikcie. A to $\mathrm{z}$ tej racji, że rzeczywisty parlamentaryzm możliwy jest wyłącznie

\footnotetext{
17 M. Weber, Etyka protestancka a duch kapitalizmu, Lublin 1994, s. 56-57. Wydaje się, że Weberowska kategoria „kapitalizmu awanturniczego” nie została zdewaluowana przez na przykład realny zwrot aksjologiczny. Mógłby on polegać na faktycznej korespondencji teorii i praktyki we współczesnym kapitalizmie, czy inaczej mówiąc - powszechnej zgodzie racjonalności i praktyki. Taka - czysto hipotetyczna zresztą - formuła kapitalizmu zasługiwałaby na miano „kapitalizmu konkordii” i pozostawałaby w tym samym polu semantycznym, co określenie „kapitalizm z ludzką twarzą" i podobne.

18 Jeżeli nawet uznamy, że opozycja pomiędzy scjentycznymi a niescjentycznymi teoriami społecznymi nie jest zbyt ostra, to jednak już w drugiej połowie XX wieku wielu socjologów, a wśród nich cytowany wcześniej Alvin W. Gouldner, Denis H. Wrong, Harold Garfinkel, Erving Goffman czy przedstawiciele szkoły frankfurckiej, Theodor W. Adorno i Jürgen Habermas, zaczęło dostrzegać sens w uwzględnianiu argumentów antyscjentystycznych w teoriach społecznych. Por. Kryzys i schizma. Antyscjentystyczne tendencje w socjologii społecznej, red. E. Mokrzycki, t. 1-2, Warszawa 1984

${ }^{19}$ P. Skrzydlewski, Btad antropologiczny $w$ teoriach społecznych, [w:] Bład antropologiczny, red. A. Maryniarczyk i K. Stępień, Lublin 2003, s. 231-232.

20 Tytuł polski: Gospodarka i społeczeństwo. Zarys socjologii rozumiejacej, w pełni odpowiada brzmieniu tytułu niemieckiego, którego ustalanie zajęło Maxowi Weberowi kilka lat życia, kiedy to opracowywał on kolejne części dzieła. Zob. D. Lachowska, Wstęp do wydania polskiego, [w:] M. Weber, Gospodarka i społeczeństwo. Zarys socjologii rozumiejacej, tłum. D. Lachowska Warszawa 2002, s. XIII-XVI .
} 
w systemie dwupartyjnym, system ten zaś z kolei tylko w sytuacji arystokratycznego panowania notabli w ramach partii" 21 .

Panowanie notabli nie jest jednak tożsame z rządami merytokracji, tym bardziej nie odpowiada koncepcji państwa dobrobytu (welfare state) Johna Rawlsa. W swojej zanadto zobiektywizowanej i podporządkowanej logice deterministycznej socjologii panowania Max Weber zauważał rozliczne zalety panowania legalnego i za tą formą rządów przemawiał nader przekonująco. Widział w niej racjonalne źródło legitymizacji władzy politycznej znajdującej impulsy do funkcjonowania w normach i przepisach prawa. Można w jego myśleniu o państwie burżuazyjnym legitymizowanym przez bezwzględny respekt dla prawa doszukiwać się wpływu pozytywizmu prawniczego. Należy jednak dodać, że kierunek ten przybrał najbardziej radykalną postać, dzięki Hansowi Kelsenowi i jego doktrynie normatywizmu prawniczego, już po śmierci Maxa Webera. Obecnie normatywizm prawniczy jest cechą charakterystyczną europejskiej, tj. kontynentalnej (z wyłączeniem brytyjskiej) kultury prawnej.

Można tu pytać, czy skrajnie racjonalistyczne poglądy na funkcje prawa jako siły organizującej życie społeczeństwa i byt gospodarczy, mogą korespondować z racjonalizmem Maxa Webera. Odpowiedź nie będzie trudna, jeśli zważyć, że według Webera nawet religijność mistyczna, czyli najbardziej wysublimowana forma doświadczenia religijnego, „daje się doskonale pogodzić z wybitnie realistycznym spojrzeniem na rzeczywistość [...] wręcz bywa, wskutek doktryn dialektycznych, jego bezpośrednim wsparciem. Co więcej, mistyka może pośrednio wychodzić na dobre racjonalnemu sposobowi życia" ${ }^{22}$. Propozycja autora dzieła Etyka protestancka a duch kapitalizmu jest z pewnością atrakcyjna od strony intelektualnej, lecz czy można ją lokować w szeroko rozumianej formule dzisiejszego kapitalizmu, zakładając, rzecz jasna, pewne korekty wynikające $\mathrm{z}$ innego momentu historycznego?

Otóż myśląc „po Weberowsku”, można by, zważywszy na relacje kapitalizmu z systemami prawa i prawem sui generis, znaleźć dla jego socjologii panowania wsparcie i zarazem etyczne dopełnienie w teorii sprawiedliwości Johna Rawlsa. Rawls posługuje się przede wszystkim kategoriami etyki Kantowskiej, a skutkiem jest przyjęcie tezy, że sprawiedliwość jest nie tylko prawem, lecz też przywilejem ludzi równych i moralnych ${ }^{23}$. Akcent położony na moralność jest nader znaczący, gdyż odsyła do idei moralnych i systemów etycznych, w tym etosu chrześcijańskiego. J. Rawls dystansuje się od takich

\footnotetext{
${ }^{21}$ M. Weber, Gospodarka i spoteczeństwo. Zarys..., s. 1066.

${ }^{22}$ M. Weber, Etyka..., op. cit., s. 95.

${ }^{23}$ Por. J. Rawls, Cantian Constructivism In Moral Theory, „The Journal Philosophy” 1980/88, s. 517. Chrześcijańscy humaniści wskazują często na powiązania sprawiedliwości z miłością. Karol Wojtyła pisze, ,że nauka moralna Starego Zakonu była oparta raczej na sprawiedliwości, nauka moralna zaś Chrystusa - na miłości. Miłość jest doskonalsza niż sprawiedliwość - i to [...] wyczuwa się raczej, niż rozumie, o tyle że w zakresie miłości umieszcza się wszelkie przejawy serca, dobroci, oddania poświęcenia, ze sprawiedliwością zaś wiążą się raczej zimny rozsądek, stanowczość i surowość. Ogromnie wielu ludzi poprzestaje na tych wyczuciach i w ten sposób radzi sobie zupełnie dobrze z życiem moralnym, a nawet dochodzi w tej dziedzinie do doskonałości”. Zob. K. Wojtyła, Elementarz etyczny, Lublin 1983, s. 92. Wydaje się, że przedstawione przez autora rozróżnienie można rozważać - w świetle tez Webera o związku etyki protestanckiej z „duchem” kapitalizmu - jako przyczynek do porównywania etosu katolickiego $\mathrm{z}$ etosem protestanckim $\mathrm{w}$ domenie aktywności ekonomicznej i innych obszarach egzystencjalnych
} 
odwołań, natomiast M. Weber próbuje wyjaśnić, stosując do tego zadania perspektywę historyczną, wpływ purytanizmu na formowanie się „ducha kapitalizmu”.

Zdaniem Marii Ossowskiej, Weber nie poświęcił należytej uwagi - a może tylko nie uznał za zjawisko istotne - niejednolitości purytanizmu w toku jego historycznej ewolucji. $\mathrm{Z}$ analizy dialektyki zmian dziejowych wynika jednak,że purytanizm wpierw dawał odpór kapitalizmowi, aby później stopniowo przed nim kapitulować. W końcu dokonał całkowitej jego legitymizacji. Można więc postawić tezę, że owe ustępstwa wynikały z presji rozwoju gospodarczego, który przecież musiał je poprzedzać ${ }^{24}$. W rezultacie w formule współczesnego kapitalizmu znajdujemy dzisiaj treści raczej metaetyczne niż stricte etyczne i swoistą deformację aksjologicznej hierarchii. Zjawisko to zaobserwował już współczesny Weberowi twórca jednej $\mathrm{z}$ najbardziej wpływowych teorii aksjologicznych Max Scheler.

Otóż Max Scheler powiada, że ,[...] najgłębsze wypaczenie hierarchii aksjologicznej, jakie kryje się w moralności nowożytnej, polega na tym, że w miarę rozwoju, w miarę zwycięstwa mentalności przemysłowej i kupieckiej nad mentalnością militarną i teologiczno-metafizyczną wartość witalna podporządkowana zostaje coraz bardziej wartościom użytecznościowym i podporządkowanie to przenika nawet najkonkretniejsze oceny wartości. [...] W miarę jak kupcy i rzecznicy przemysłu dochodzili w państwach (zwłaszcza w państwach zachodnich) do władzy, a ich osąd, ich smak i ich skłonności stawały się czynnikami, które przesądzały również o twórczości duchowej w kulturze, w miarę jak podstawowe ontologiczne symbole i przedstawienia, które z konieczności narzucała im własna działalność, wyparły dawniejsze symbole religijne, również ich sposób wartościowania stał się wszędzie czynnikiem kształtującym w ogóle «moralność»"25. Schelerowskie rozpoznanie zdradza wyraźne parantele z utylitarystyczną etyką Jeremy'ego Benthama i doskonale ilustruje przede wszystkim mentalność oraz wynikającą z niej etykę protestantyzmu. Należy tutaj powiedzieć, że w przekroju historycznym protestantyzm wyróżniał się większą niż katolicyzm dynamiką w zakresie kreowania wartości ekonomicznych. Przykładem może być chociażby fakt, że protestanci (purytanie, wyznawcy kwakryzmu, prezbiterianie), zasiedlający w XVII wieku zamorskie kolonie angielskie na kontynencie amerykańskim, zaczynali egzystencję pionierów od budowy obiektów gospodarczych. Wytwarzali tam dające się spieniężyć dobra, a miejscem modlitwy były co okazalsze domostwa. Natomiast imigranci katoliccy przeważnie budowali wpierw kościoły, by później dopiero inicjować działalność ekonomiczną. Życie duchowe i religijne przedkładali bowiem nad egzystencję podporządkowaną dyktatowi materialnego zysku i ekonomicznego awansu.

Już choćby ten przykład przemawia za tezą, w myśl której etos protestancki od etosu katolickiego odróżniał etyczny pragmatyzm ${ }^{26}$. W odróżnieniu tym pomocne jest

\footnotetext{
${ }^{24}$ M. Ossowska, Moralność mieszczańska, wyd. 2, Wrocław-Warszawa-Kraków-Gdańsk-Łódź 1985, s. 225.

${ }^{25}$ M. Scheler, Resentyment a moralność, Warszawa 1977, s. 190.

${ }^{26}$ Pragmatyzm jest integralną zasadą tzw. etyki sytuacyjnej, której główne postulaty sformułował anglikański teolog Joseph Fletcher w klasycznym już dziś dziele z 1966 r. - Situation Ethics (Etyka sytuacyjna). Kwintesencją pragmatyzmu jest założenie, że warunkiem słuszności czynu jest jego skuteczność. Natomiast na pytanie o to, jakie skutki mają mieć na celu ludzkie postępki, zwolennicy etyki sytuacyjnej zwykli odpowiadać, że miarą przesądzającą o powodzeniu bądź niepowodzeniu zarówno myśli, jak i czynu jest miłość. Por. P. Vardy, P. Grosch, Etyka. Poglady
} 
odwołanie się do słynnego wniosku Maxa Webera. Otóż uczony wskazywał na etykę protestancką jako kanon wartości noszący znamiona, mówiąc przenośnie, ,powinowactwa Z wyboru” z ,duchem kapitalizmu”. Natomiast akcent na traktowanie pracy jako powołania czy misji, jak również „głoszenie bożej chwały przez właściwe gospodarowanie darami, jakie Bóg ofiarował ludzkości, nadało znaczenie niezmordowanemu rachunkowi korzyści i pogoni za zyskiem, mającym na celu wzmocnienie w sobie ducha inicjatywy gospodarczej jako przeciwieństwa zwykłej chciwości i zachłanności” ${ }^{27}$. Tezę tę można również obecnie odnosić do poczynań wielu jednostek, ale w większej skali wyraża się ona w praktykach i postawach wyczerpujących „znamiona” tzw. political correctness.

Mówiąc o recepcji myśli socjologicznej Maxa Webera do współczesnych teorii próbujących objaśnić istotę kapitalizmu w jego obecnej postaci, należy stwierdzić, że jest ona wciąż zauważana i komentowana. Co znamienne, nawet w analizach krytycznych widać estymę dla jego koncepcji uprawomocnienia władzy czy innych ustaleń z zakresu socjologii. Uznaniem cieszą się przemyślenia w przedmiocie relacji zachodzących pomiędzy systemem ekonomicznym a systemem społecznym. Z kolei Weberowska teoria biurokracji jako systemu idealnego okazała się jedną $\mathrm{z}$ największych porażek niemieckiego uczonego. Nie została jednak zapomniana i jest w naukach o organizacji i zarządzania uznawana za „urządzenie”, dla którego nie ma już miejsca w konkurencyjnej gospodarce wolnego rynku. Czyni ją to użyteczną w dydaktyce jako przykład systemu anachronicznego, od którego powinna się dystansować każda organizacja zorientowana na rozwój Na tym - generalnie rzecz ujmując - miałaby polegać obecność Maxa Webera w teoretycznej formule kapitalizmu. Stwierdzenie to nie dotyczy już jednak sfery praktycznej. Koncepcje i tezy Maxa Webera zostały wyparte przez nowoczesne modele ekonomiczne, bardziej $\mathrm{z}$ pewnością użyteczne $\mathrm{w}$ warunkach gospodarki nadzwyczaj dynamicznej, złożonej, wielozjawiskowej. Na ich tle propozycje Maxa Webera nie mogłyby już występować nawet w funkcji „brzytwy Ockhama”, a tym bardziej - precyzyjnych instrumentów stymulowania i kontroli procesów obserwowanych w globalizującej się z nie do końca zrozumiałą determinacją gospodarce.

\section{WEBERIAN RÉSUMÉ. A REFLECTION ON THE PRESENCE OF MAX} WEBER'S THOUGHT IN THE FORMULA OF MODERN CAPITALISM

Max Weber (1864-1920) is one the "founding fathers" of modern sociology. His sociology, compliant with the principles of rationality and objectivity, named by Weber himself "understanding sociology", is a part of the humanistic orientation whose core is the thesis on essential difference between the natural world and the cultural world. In his classic Protestant Ethics and the Spirit of capitalism (1905), Weber tries to prove that the genesis and existence of capitalism may only be comprehended taking into account the influence of the protestant ethics on the shaping of entrepreneurial behaviors in the western societies. In the overall positive response Weber's theories there occur certain negative tones. Criticism refers mainly to the theory of bureaucracy as the ideal system, which in the formula of modern management of both economic entities and public institution is no longer recognized and has been replaced by concepts paying more attention to the role of human

i problemy, Poznań 1995, s. 126. W świetle tak rozumianego pragmatyzmu protestancki homo oeconomicus wydaje się kategorią relatywną.

${ }^{27}$ G. Ingham, op. cit., s. 81 . 
capital. Bureaucracy is considered as anachronic system. There are also objections to the fact that Weber presented his dialectic of the development of capitalism in accurately, treating Puritanism as the force with the same potential at every stage of the process. In the formula of modern capitalism, expansive and implemental in various model approaches, each of which assumes the primacy of profit, one may find numerous references of Weber's thesis on the benefit account as the main drive for human enterprise and seeking legitimization in ethics.

Keywords: Max Weber, Protestant ethics, Spirit of capitalism, bureaucracy, management, legitimization, formula of modern capitalism.

\section{LITERATURA}

[1] Bendix R., Max Weber. Portret uczonego, thum. K. Jakubowicz, Warszawa 1975.

[2] Bulita W., W poszukiwaniu arché. Wprowadzenie do teorii nowoczesności Ágnes Heller, [w:] Á. Heller, Eseje o nowoczesności, tłum. J. P. Hudzik, W. Bulita, T. Markiewka, R. Kubicki, Toruń 2012.

[3] Czainska K., Odkryć zarzadzanie. Wybrane koncepcje, Warszawa 2010.

[4] Gouldner A.W., Anty-minotaur, czyli mit socjologii wolnej od wartości, [w:] Kryzys $i$ schizma. Antyscjentystyczne tendencje $w$ socjologii wspótczesnej, tłum. E. Morawska, red. E. Mokrzycki, t. 2, Warszawa 1984.

[5] Heller Á., Eseje o nowoczesności, tłum. J. P. Hudzik, W. Bulita, T. Markiewka, R. Kubicki, Toruń 2012.

[6] Ingham G., Kapitalizm, tłum. S. Królak, K. Sosnowska,Warszawa 2011.

[7] Jaremczuk K., Koncepcje zarządzania wspótczesna organizacją, [w:] Zarządzanie w zarysie, red. K. Jaremczuk, Przemyśl-Rzeszów 2011.

[8] Kehrer G., Wprowadzenie do socjologii religii, Kraków 1996.

[9] Lachowska D., Wstęp do wydania polskiego, [w:] M. Weber, Gospodarka i społeczeństwo. Zarys socjologii rozumiejacej, Warszawa 2002.

[10] Mencwel A. Wyobraźnia antropologiczna. Próby i studia, Warszawa 2006.

[11] Ossowska M., Moralność mieszczańska, wyd. 2, Wrocław-Warszawa-Kraków-GdańskŁódź 1985.

[12] Rawls J., Cantian constructivism in moral theory, „The Journal Philosophy” 1980/88.

[13] Scheler M., Resentyment a moralność, Warszawa 1977.

[14] Schultz T.W., Ekonomia kapitału ludzkiego, tłum. A. Kliber, P. Kliber, Warszawa 2014.

[15] Skrzydlewski P., Bład antropologiczny $w$ teoriach społecznych, [w:] Btad antropologiczny, red. A. Maryniarczyk, K. Stępień, Lublin 2003.

[16] Szacki J., Historia myśli socjologicznej. Część druga, wyd. 2, Warszawa 1983.

[17] Szczerski K., Porządki biurokratyczne, Kraków 2004.

[18] Vardy P, Grosch P., Etyka. Poglady i problemy, Poznań 1995.

[19] Weber M., Etyka protestancka a duch kapitalizmu, tłum. J. Miziński, Lublin 1994.

[20] Weber M., Gospodarka $i$ spoteczeństwo. Zarys socjologii rozumiejacej, thum. D. Lachowska, Warszawa 2002.

[21] Wojtyła K., Elementarz etyczny, Lublin 1983.

DOI:10.7862/rz.2015.hss.14

Przesłano do redakcji: styczeń 2015

Przyjęto do druku: maj 2015 